\title{
МІЖНАРОДНІ ПРАВОВІ СТАНДАРТИ ФОРМУВАННЯ НАЛЕЖНИХ ДОКАЗІВ
}

Kpem Г. P.

Стаття присвячена розкриттю напрацьованих ЄСПЛ міжнародних стандартів належності доказів як їх процесуальної властивості, встановлення якої спрямоване на відображення наявності та форми зв'язку між доказом і фактом/обставиною, що підлягає доказуванню. Розкривається коло випадків, за яких ЄСПЛ звертається до оцінки доказів із точки зору їх належності.

На основі проведеного дослідження узагальнюється система міжнародних стандартів належності доказів, сформованих у практиці ЄСПЛ.

Ключові слова: стандарти доказування, міжнародні стандарти доказування, міжнародні стандарти формування доказів, міжнародні стандарти належності доказів.

Статья посвящена раскрытию наработанных ЕСПЧ международных стандартов относимости доказательств как их процессуального свойства, установление которого направлено на отражение наличия и формы связи между доказательством и фактом/обстоятельством, подлежащим доказыванию. Раскрывается круг случаев, при которых ЕСПЧ обращается к оценке доказательств с точки зрения их относимости.

На основе проведенного исследования обобщается система международных стандартов относимости доказательств, сформированных в практике ЕСПЧ.

Ключевые слова: стандарты доказывания, междуна родные стандарты доказывания, международные стандарты формирования доказательств, международные стандарты относимости доказательств.

The article is dedicated to disclosure of ECHR international standards of the relevance of evidences. It is justified that, from the ECHR's view, it is the duty of establishing the relevance of evidences relies on national courts, which must evaluate from this point of view all available evidences.

A number of cases in which the ECHR refers to the evaluation of evidences in terms of their relevance are disclosed. These include: 1) cases where it assesses the applicant's alleged breach of the right to a fair trial (as a result of the national courts failing to comply with article 6 \& 3 of the European Convention from 04.11.1950 in its connection with paragraph 1 article 6 of the Convention); 2) cases where it establishes the absence in judgments given by national courts of conclusions on the relevance of evidences and the reasons and motives for declaring particular evidences in inrelevable.

On the basis of the conducted research, the system of international standards of the relevance of evidences, established in the practice of ECHR, is generalized. It include: 1) the evaluation of evidences in the light of their relevance is the duty of national courts; 2) from the point of view of relevance, both the available evidences and the evidences submitted by the defense (expert opinion) or on the receipt of which the petition filed (questioning of witnesses and experts) are subject to evaluation; 3) in assessing the relevance of evidences, including that submitted by the defense or receiving the defense petition,

Крет Г. Р., 2019 national courts should determine their relevance for establishing the facts / circumstances of criminal proceedings; 4) national courts are entitled to refuse a defense the submission of evidencei or the satisfaction of a petition for their receipt only if such evidences, which is declared inrelevable; 5) the refusal of the national courts to the defense to present evidences or to satisfy the petition for their receipt without justifying their inrelevance leads to a restriction of the right to a defense incompatible with the guarantees of a fair trial enshrined in article 6 of the European Convention from 04.11.1950; 6) the reflection by the national courts of the assessment of the evidences in terms of their relevance and its motives in the court decisions taken.

Key words: standards of proof, international standards of proof, international standards of evidences formation, international standards of the relevance of evidences.

Постановка проблеми та їі актуальність. У кримінальному процесі країн як романо-германської, так і англосаксонської правових систем однією з процесуальних властивостей доказів $€$ їх належність, встановлення якої спрямоване на відображення наявності та форми зв'язку між доказом і фактом/обставиною, що підлягає доказуванню. У вітчизняному кримінальному процесі належність доказів визначається у ст. 85 КПК України шляхом закріплення поняття належних доказів. Вказане визначення ґрунтується на історично сформованому вітчизняному досвіді до визначення процесуальних властивостей доказів і відображає низку міжнародних стандартів належності доказів, сформованих у практиці ЄСПЛ.

Аналіз останніх досліджень і публікацій. У доктрині кримінального процесу дослідженню поняття, змісту та використання міжнародних стандартів доказування присвячена істотна увага вчених-процесуалістів. Зокрема, вказану проблематику досліджують у своїх працях В.Д. Басай, В.В. Вапнярчук, І.В. Гловюк, В.О. Гринюк, О.В. Капліна, С.О. Ковальчук, В.І. Маринів, М.А. Погорецький, Х.Р. Слюсарчук, А.С. Степаненко, В.М. Трофименко, О.Г. Шило та інші вітчизняні і зарубіжні вчені. Проте система та зміст міжнародних стандартів формування доказів, у тому числі стандартів їх належності, науковцями не досліджувалися. Розкриття вказаних питань дозволить визначити як відповідність вітчизняного кримінального процесуального законодавства у досліджуваній площині міжнародним стандартам доказування, так і напрями використання міжнародних стандартів належності доказів національними судами.

Метою цієї статті $€$ визначення на основі практики ЄСПЛ системи міжнародних стандартів належності доказів.

Виклад основного матеріалу. Міжнародні стандарти формування належних доказів сформовані у практиці ЄСПЛ у процесі надання ним оцінки дотри- 
манню права на справедливий судовий розгляд, закріпленого ст. 6 Європейської конвенції від 04.11.1950р., та з урахуванням його сталого підходу до оцінки доказів, відповідно до якої вона здійснюється національними судами.

У своїй практиці ЄСПЛ неодноразово звертав увагу на обов'язок національних судів надати оцінку доказам і з точки зору їх належності. При цьому початково здійснювана національними судами оцінка доказів із точки зору їх належності пов'язувалася ЄСПЛ виключно з доказами, які прагнула подати сторона захисту. Зокрема, він неодноразово зазначав, що за загальним правилом національні суди повинні оцінювати подані їм докази, а також належність доказів, які обвинувачені намагаються подати (п. 68 рішення від 06.12.1988 р. у справі "Barberà, Messegué and Jabardo v. Spain", п. 33 рішення від 22.04.1992 р. у справі “Vidal v. Belgium”) [1; 2].

У подальшому ЄСПЛ уточнив наведену позицію, вказуючи на обов'язок національних судів оцінити із точки зору належності не лише докази, які прагне подати сторона захисту, але й усі наявні докази. Так, згідно його позиції вітчизняний суддя повинен оцінити належність і доказове значення усіх наявних доказів, включаючи висновки експертів, а повноваження суду в цій сфері $\epsilon$ дуже обмеженими (п. 174 рішення від 11.12.2008 р. у справі “Mirilashvili v. Russia”) [3].

Вказуючи на обмеженість своїх повноважень щодо оцінки доказів із точки зору вказаної процесуальної властивості, ЄСПЛ наголошує, що висловлення думки щодо належності поданих і відхилених доказів не $\epsilon$ функцією сСуду (п. 34 рішення від 22.04.1992 р. у справі “Vidal v. Belgium”) [2], але звертається до їі встановлення у двох випадках: 1) якщо ним надається оцінка стверджуваному заявником порушенню права на справедливий судовий розгляд внаслідок недотримання національними судами передбаченого п. 3d ст. 6 Європейської конвенції від 04.11.1950 р. права обвинуваченого допитувати свідків обвинувачення або вимагати, щоб їх допитали, а також вимагати виклику й допиту свідків захисту на тих самих умовах, що й свідків обвинувачення у його взаємозв'язку з п. 1 ст. 6 Конвенції [4]; 2) якщо ним встановлено відсутність у судових рішеннях, ухвалених національними судами, висновків щодо належності доказів та підстав і мотивів визнання окремих доказів неналежними.

У контексті дотримання національними судами п. 3d ст. 6 Європейської конвенції від 04.11.1950р. ЄСПЛ звертається до оцінки належності показань, які могли бути надані свідками захисту, про допит яких стороною захисту заявлялися клопотання та у задоволенні яких було відмовлено національними судами. Зокрема, у п.п. 72-73 рішення від 14.02.2008 р. у справі “Dorokhov v. Russia” ЄСПЛ зазначає, що відповідно до обвинувального висновку у 1997 р. заявник отримав першу автомашину у вигляді хабаря. Заявник стверджував, що він придбав ії і що В. та Г. бачили, як він платив за неї. У заяві від 09.06.1999 р. заявник пояснив, що громадяни В. та Г. могли б дати показання і вказав їх місцезнаходження. Тому клопотання про виклик свідків було досить обґрунтованим, відповідало предмету обвинувачення i, можливо, могло б призвести до виправдання заявника. Іншими словами, клопотання не було явно неналежним до справи і таким, на яке суд не був би зобов'язаний надавати відповідь.
Суд першої інстанції повністю відхилив пропозицію заявника подати показання свідків без будь-яких обґрунтувань. Суд касаційної інстанції не вжив заходів щодо твердження заявника стосовно відмови нижчестоящого суду викликати свідків. Заявник клопотав перед судом першої інстанції про внесення змін до протоколу судового засідання шляхом внесення в нього клопотання про виклик громадян В. і Г, однак це клопотання було відхилено [5].

Поряд із цим оцінка належності надавалася ЄСПЛ показанням, які могли бути надані свідками обвинувачення, допитаними раніше за відсутності сторони захисту, про допит яких останньою заявлялися клопотання, у задоволенні яких було відмовлено національними судами. Так, у п.п. 226 і 227 рішення від 11.12.2008 р. у справі “Mirilashvili v. Russia” ЄСПЛ вказує, що захист по відношенню до обвинувачення перебував у несприятливому становищі: у той час як обвинувачення могло допитувати ключових свідків безпосередньо, захист був позбавлений такої можливості.

Захисту було відмовлено у поданні письмової заяви свідка, яка стосується предмета провадження, та його попередніх показань. Докази, подані захистом, були належними та істотними. Крім того, три спірні свідки були ключовими свідками обвинувачення. Отримуючи від них нові показання, захист прагнув не тільки створити виправдувальні докази, але й оскаржити докази, зібрані проти заявника. За конкретних обставин справи, коли заявник не мав можливості допитати декількох ключових свідків у суді або у досудовій стадії, відмова приєднати до справи їх письмові показання та заяви, отримані захистом, була виправданою. Суд підкреслив, що він не висловлює позиції щодо можливої оцінки таких заяв і показань - це $\epsilon$ прерогативою національних судів [3].

Виходячи з автономного тлумачення вжитого у п. 3d ст. 6 Європейської конвенції від 04.11.1950 р. терміну «свідок», ЄСПЛ надає оцінку належності висновків експертів обвинувачення та захисту і їх показань. На його думку, роль спеціаліста у розгляді потрібно відрізняти від ролі свідка, який повинен повідомити суду свої особисті спогади про конкретну подію. Проте це не означає, що перевірка експертних даних не охоплюється п. 3d ст. 6 Конвенції у взаємозв'язку з п. 1 ст. 6 Конвенції (п. 711 рішення від 25.07.2013 р. у справі “Khodorkovskiy and Lebedev v. Russia”) [6].

До оцінки належності висновків експертів, які подавалися стороною захисту та у приєднанні яких було відмовлено національними судами, ЄСПЛ звертається у п. 723 вказаного рішення, в якому зазначає, що деякі інші висновки і дослідження, подані захистом, також переважно стосувалися інших галузей знань, таких як економічний аналіз або облік. Це стосується пояснень Петрової та її письмового висновку, які стосувалися, зокрема, певних практик обліку, пояснень Бочко і висновку Уральського відділення Російської академії наук, які оцінювали економічний вплив діяльності торгівельних компаній у зонах пільгового оподаткування, та висновку Плешкової, який стосувався й економічної здійсненності інвестиційної програми «Апатиту». Суд відхилив ці висновки у сукупності, не розрізняючи питання, порушені в них. У той час як невибірковий підхід загрожує небезпеками, Європейський Суд готовий визнати, що первинна причина неприйняття цих виснов- 
ків також полягала в їх неналежності або марності, що відноситься до сфери розсуду суду першої інстанції [6].

Питання про належність доказів встановлюється ЄСПЛ $з$ урахуванням обставин конкретної справи, у зв'язку з чим він може констатувати як наявність, так і відсутність порушень гарантій справедливого судового розгляду, закріплених ст. 6 Європейської конвенції від 04.11.1950 р., допущених національними судами внаслідок неправильного встановлення вказаної процесуальної властивості доказів.

За умови наявності зв'язку між змістом доказу та фактом, який підлягає встановленню, ЄСПЛ констатує порушення національними судами вимог п. 3d ст. 6 у взаємозв'язку з п. 1 ст. 6 Європейської конвенції від 04.11.1950 р. Так, у п.п. 187 і 189 рішення від 13.07.2006 р. у справі “Popov v. Russia” ЄСПЛ вказує, що, відмовляючись від допиту пані Р. та пана Х., суд першої інстанції не став розглядати питання про те, чи могли їх показання мати важливість для розгляду справи. Судячи з того, що попередні клопотання захисту про допит цих свідків неодноразово задовольнялися як під час досудової стадії, так і у процесі судового розгляду, випливає, що національні органи згодні з тим, що їх показання могли бути належними. Враховуючи конкретні обставини цієї справи, суд вважає, що у справі було допущено порушення п. 3d у взаємозв'язку з п. 1 ст. 6 Конвенції [7].

За відсутності ж такого зв'язку ЄСПЛ вказує на відсутність порушень вимог п. 3d ст. 6 у взаємозв'язку з п. 1 ст. 6 Європейської конвенції від 04.11.1950 р. Зокрема, у п.п. 74-75 рішення від 14.02.2008 р. у справі “Dorokhov v. Russia” ЄСПЛ зазначає, що клопотання заявника явно належало до предмета обвинувачення. Як було підтверджено захистом у процесі судового розгляду, ні громадянка В., ні громадянка Г. не бачили, що він сплачував пану Ш. грошові кошти за автомобіль. За його словами, він передав пану Ш. закритий конверт і не сказав, що було всередині. Тільки пізніше він повідомив громадянці Г., що він заплатив пану Ш. грошові кошти за автомобіль.

Тому доказова значимість показань свідків громадянок Г. і В. $€$ дуже низькою. Доводи ж на користь винності заявника були досить вагомими. Декілька людей свідчили у судовому засіданні про те, що вони дали йому хабар у вигляді автомобіля. Тому, навіть якби суд викликав і заслухав Г. і В., їх показання, швидше за все, не призвели б до виправдання заявника. Повна відмова національних судів викликати свідків з боку захисту, зокрема, в конкретних обставинах цієї справи не вплинула на справедливість судового розгляду. Тому не мало місця порушення п. 3d ст. 6 у взаємозв'язку з п. 1 ст. 6 Конвенції [5].

Поряд із наданням оцінки доказам із точки зору належності у випадках встановлення стверджуваного заявником порушення п. 3d ст. 6 у взаємозв'язку вказаної процесуальної властивості доказів, у разі констатації ним ненаведення судових рішень національних судів і висновків щодо належності доказів та підстав, мотивів визнання окремих доказів неналежними.

У своїй практиці ЄСПЛ звертає увагу на необхідність відображення встановлених національними судами процесуальних властивостей доказів, у тому числі їх належності, в ухвалюваних ними судових рішеннях.
Так, національні суди у першу чергу повинні встановлювати допустимість доказів, їх належність і вагомість, які повинні відображатися у рішенні (п. 30 рішення від 11.10.2011 р. у справі “Fomin v. Moldova”) [8], а повне мовчання у рішенні суду щодо питання належності поданих і відхилених доказів, як і загалом винуватості чи невинуватості обвинуваченого, не відповідає концепції справедливого судового розгляду, яка $\epsilon$ основою ст. 6 Конвенції (п. 34 рішення від 22.04.1992 р. у справі "Vidal v. Belgium") [2].

Наведений підхід ЄСПЛ вказує на тісний взаємозв'язок встановлення належності доказів не лише зі змагальністю судового розгляду, рівністю сторін, правом на захист, але й з умотивованістю судових рішень. 3 огляду на викладені позиції ЄСПЛ щодо оцінки доказів із точки зору їх належності, здійснюваної національними судами, останні у постановлюваних ними судових рішеннях повинні наводити: 1) вказівку на докази, належність яких встановлена, наявна їх значимість для встановлення фактів/обставин кримінального провадження; 2) підстави і мотиви визнання наявних доказів неналежними; 3) підстави і мотиви відмови стороні захисту у поданні доказів або задоволенні клопотання про їх отримання.

3 позиції ЄСПЛ вбачається, що такий обов'язок національних судів не $\epsilon$ абсолютним і в окремих випадках може зазнавати обмежень. Зокрема, ЄСПЛ зазначає, що право бути почутим включає не лише можливість звертатися із заявами до суду, але й відповідний обов'язок суду викласти у своїх мотивах причини, через які відповідні заяви були прийняті або відхилені. Цей обов'язок завжди містить застереження, що суд може вважати зайвим відповідати на аргументи, які $\epsilon$ явно неналежними, необґрунтованими, образливими чи іншим чином неприпустимими через чіткі правові положення чи налагоджену судову практику стосовно аналогічних видів аргументів (п. 37 рішення від 01.07.2003 р. у справі "Suominen v. Finland") [9].

Висновки. Вагомий внесок у розробку міжнародних стандартів формування належних доказів здійснив ЄСПЛ, у практиці якого напрацьовано такі стандарти: 1) оцінка доказів із точки зору їх належності $\epsilon$ обов'язком національних судів; 2) із точки зору належності оцінці підлягають як наявні докази, так і докази, які подаються стороною захисту (висновок експерта) або про отримання яких заявлено клопотання (допит свідків та експертів); 3) оцінюючи належність доказів, у тому числі тих, які подаються стороною захисту або про отримання яких стороною захисту заявлено клопотання, національні суди повинні з'ясувати їх значимість для встановлення фактів/обставин кримінального провадження; 4) національні суди мають право відмовити стороні захисту у поданні доказів або задоволенні клопотання про їх отримання лише у разі визнання таких доказів неналежними; 5) відмова національних судів стороні захисту у поданні доказів або задоволенні клопотання про їх отримання без обґрунтування їх неналежності призводить до обмеження права на захист, несумісного з гарантіями справедливого судового розгляду, закріпленими ст. 6 Європейської конвенції від 04.11.1950 р.; 6) відображення національними судами оцінки доказів із точки зору їх належності та її мотивів в ухвалюваних судових рішеннях. 


\section{Література}

1. Case of Vidal v. Belgium: Judgment of the European Court of Human Rights from 22 April 1992. URL: http://echr.ketse.com/doc/12351.86-en-19920422/view/.

2. Case of Barberà, Messegué and Jabardo v. Spain: Judgment of the European Court of Human Rights from 06 December 1988. URL: http://hudoc.echr.coe.int/ eng?i=001-57429.

3. Case of Mirilashvili v. Russia: Judgment of the European Court of Human Rights from 11 December 2008. URL: https://www.legal-tools.org/doc/0e491f/pdf/.

4. Конвенція про захист прав людини і основоположних свобод від 04.11.1950 р., ратифікована Законом України від 17.07.1997 p. № 475/97-BP. URL: http://zakon.rada.gov.ua/ laws/show/995_004.

5. Case of Dorokhov v. Russia: Judgment of the European Court of Human Rights from 14 February 2008. URL: http://hudoc.echr.coe.int/eng?i=001-85079.
6. Case of Khodorkovskiy and Lebedev v. Russia: Judgment of the European Court of Human Rights from 25 July 2013. URL: http://hudoc.echr.coe.int/eng?i=001-122697.

7. Case of Popov v. Russia: Judgment of the European Court of Human Rights from 13 July 2006. URL: http://hudoc.echr.coe.int/eng?i=001-76341.

8. Case of Fomin v. Moldova: Judgment of the European Court of Human Rights from 11 October 2011. URL: http://echr.ketse.com/doc/36755.06-en-20111011/view/.

9. Case of Suominen v. Finland: Judgment of the European Court of Human Rights from 1 July 2003. URL: http://hudoc.echr.coe.int/eng?i=001-61178.

Kpem Г. P., кандидат юридичних наук, доцент, суддя Касаційного кримінального суду у складі Верховного Суду 